
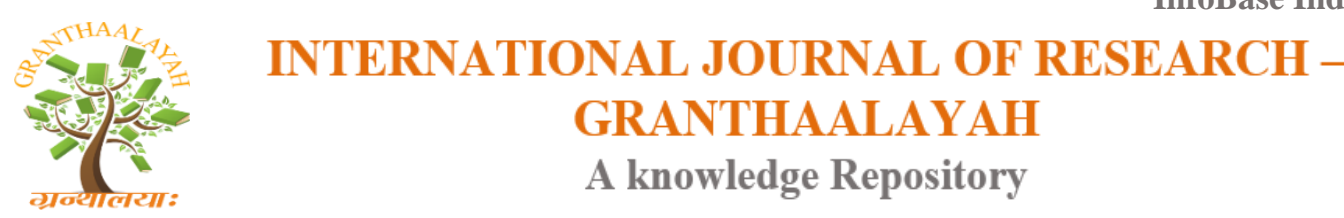

Management

\title{
BEHAVIORAL FINANCE- EVIDENCE FROM TEHRAN STOCK EXCHANGE
}

\author{
Mojtaba Mortezaee $^{* 1}$, Davoud Sanji ${ }^{2}$, Majid Govahi ${ }^{3}$ \\ ${ }^{* 1,2,3}$ MS.C. Of Accounting, Islamic Azad University of Mashhad, Iran
}

DOI: https://doi.org/10.29121/granthaalayah.v4.i12.2016.2395

\begin{abstract}
A capital market is a vast and controversial issue in financial matters and especially behavioural finance. Indeed, behavioural finance is aim to survived the influence of the psychological variables on financial markets transformation. It should be noted that financial investors may have different level of rational behaviour, which leads to different kinds of effects, which can elaborate market inconsistency. Classical finance assumes the investors as rational peoples who try to select the most lucrative and efficient portfolio considering expected financial risk. Behavioural finance model mainly focus on psychological parameters. Tehran Stock Exchange (TSE) is affected by many financial and economic variables. Investor in this financial market is affected by different data. Present study is aim to examine psychological variables beside political, economic and capital market features factors. Research data collects in 2015 and analysis by LISREL software. The results reveal that political, economic and psychological parameters respectively are the most important variables which affect the investor decision making behaviour. The internal financial reports and market return are less effective factor in their financial decision behavior.
\end{abstract}

Keywords: Behavioural Finance; Investor Decision; Psychological Variables; Tehran Stock Exchange (TSE).

Cite This Article: Mojtaba Mortezaee, Davoud Sanji, and Majid Govahi. (2016). "BEHAVIORAL FINANCE- EVIDENCE FROM TEHRAN STOCK EXCHANGE." International Journal of Research - Granthaalayah, 4(12), 79-84. https://doi.org/10.29121/granthaalayah.v4.i12.2016.2395.

\section{Introduction}

Behavioural finance is aim to examine and elaborate the effect of psychological variables on financial markets changes. In other words, behavioural finance assumes that financial markets inefficiency and psychological matters have a close correlation. On the other hand, the classical finance concentrated on capital markets as efficient market with rational investors. Actually, psychological assumptions help to understand investor financial personality. In other words, they 
try to understand why investors make specific financial decisions. Behavioural finance can provide a various viewpoints, which could have high complexity. All human emotions participate in each financial investment decision making (Birau, 2011).

The questions arise about financial market changes is that, are the traditional models able to explain these changes? Behavioural finance claims that can respond to this changes but not clearly. Efficient market hypothesis (Fama, 1998) explains that market efficiency and market return in long-term. Consistent with the market efficiency hypothesis that the fluctuations in markets are not expected results. According market efficiency certain changes can be due to methodology, especially in long-term return. But, behavioural finance knows the financial markets informational inefficient (Ritter, 2003). Thus, this question arises that is how the psychological matters about investor behaviour can elaborate capital markets deficiencies. Hill (1997) examines investor's behaviour according to political-social changes in South Eastern Asia market. Chang (2015) investigated economic variables such as interest rate and inflation rate on financial behaviour of investors. Gregor (2001) investigated the effective factors on investors' behaviour in New York Stock Exchange based on their expectations and their risk tolerance.

\section{Conceptual Framework}

As previously noted, classical finance hypothesis assumes that investors behave logical and naturally they tend to choose an efficient investment portfolio. The efficient market has been attended by many researchers. In most studies, the subject was not financial markets or stock exchanges markets. Besides, in Efficient Markets Hypothesis we suppose that investor faced no limitation about information accessibility, thus stock prices are reliable criterion.

According to Fama definition from desirable financial market and similar theories about efficient financial market, in an efficient market at any stage the actual price will be a good estimate of its inherent value. Basically, in such a market, no investment plan or investor can earn excess riskadjusted average returns, or average returns greater than are warranted for its risk (Barberis \& Thaler, 2003). Market efficiency theory was accepted mainly due to arbitrage assumptions but this viewpoint was unrealistic because did not consider investment strategies related to prices. Indeed, arbitrage may leads to mispricing matters. Arbitrage means simultaneous transactions in different markets for advantageously different prices (Sharpe \& Alexander, 1990). Gromb and Vayanos (2010) financial market fluctuations and arbitrage are two complementary concepts.

An efficient market has three specifications: allocation issue and operational and informational efficiency. Allocation efficiency refers to the optimum allocation of financial resources. Operational efficiency means reasonable cost transfer of financial funds which leads to equilibrium prices. Informational efficiency as previously noted is availability of information. Therefore, a market is efficient considering information ability to make economic profits (Ross, 1987). Thus, arbitrage, costs and risk are not able to create unusual profits. Malkiel (2003) proposed that: A capital market in efficient situation must be correctly reflects all pertinent information to show actual prices.

Present article focus on informational efficiency in financial market. In an efficient market considering information, price changes cannot be predicted by any market participants. Thus, 
prices determines through independent variables (Samuelson, 1965). In this case, fundamental analysis and technical analysis techniques won't be able to create excess returns (Birau, 2011; Houthakker, 1996). If we consider the investor rational, so how can elaborate their decision making behaviour in financial markets as irrational environment. We expect that behavioural finance have an appropriate answer for this paradox. Behavioural finance is a new approach to capital market or analysis financial markets, we expect that this new assumption find its role in financial decision making process. Financial decision making considering behavioural finance, can help us to have a better understanding of market changes (Mathews, 2005).

Cognitive psychologist in contrast to behaviourist focuses on information processing models and decision-making under risk. And also in mathematical psychology, examine to found out an appropriate scale to be applicable in different situations (Luce, 2000). Sewell (2010), defined behavioural finance as influence of psychology on the behaviour of financial practitioners and its subsequent effect on markets. Barberis and Thaler (2001) consider that behavioural finance as arbitrage limitation. Fromlet (2001) knows behavioural finance a combination of financial and psychological maters. Thus, behavioural finance combines individual and social psychology with classical financial theory to understand the performance of stock markets. Perhaps it is wise to note that, behavioural finance it is an alternative solution to the difficulties faced by the classical theory in explaining certain financial phenomena.

\section{Methodology}

In present study we use correlation and regression analyses by LISREL software. In order to collect data use Likert scale questionnaire. In primary stage use Cronbach's alpha test to estimate questionnaire reliability (86\%). 258 questionnaire include 40 question were correctly fill by investors. According to Bartlett's test of Sphericity (Chi-square $=28332.112$, Sig. $=0.000$ ) and test statistic of KMO is equal to 0.976 , which prove sample adequacy.

Research hypothesis in order to examine financial investor behavior are as follows:

$\mathrm{H}_{1}$ : There is meaningful correlation between Political variables and financial behavior.

$\mathrm{H}_{2}$ : There is meaningful correlation between Economic variables and financial behavior.

$\mathrm{H}_{3}$ : There is meaningful correlation between Psychological variables and financial behavior.

$\mathrm{H}_{4}$ : There is meaningful correlation between internal financial reports and financial behavior.

$\mathrm{H}_{5}$ : There is meaningful correlation between Market return and investor financial behavior.

\section{Findings}

Table 1: Economic, Political, Psychological, Internal financial reports and Market return factors.

\begin{tabular}{|c|c|c|c|c|c|}
\hline & Economic & Political & Psychological & $\begin{array}{c}\text { Internal financial } \\
\text { reports }\end{array}$ & Market return \\
\hline 1 & Interest Rate & Internal events & $\begin{array}{c}\text { Stock Market } \\
\text { News }\end{array}$ & Financial ratios & $\begin{array}{c}\text { Risk and } \\
\text { Return }\end{array}$ \\
\hline 2 & $\begin{array}{c}\text { Foreign } \\
\text { Investments }\end{array}$ & $\begin{array}{c}\text { External events } \\
\text { (U.S news) }\end{array}$ & $\begin{array}{c}\text { Firms } \\
\text { announcements }\end{array}$ & Balance sheet & Earning Yield \\
\hline 3 & Inflation Rate & External events & Broker & Income Statement & Stock Price \\
\hline
\end{tabular}




\begin{tabular}{|c|c|c|c|c|c|}
\hline & (E.U news) & Suggestions & & trend \\
\hline 4 & $\begin{array}{c}\text { Exchange } \\
\text { Rate }\end{array}$ & $\begin{array}{c}\text { External events } \\
\text { (Asia news) }\end{array}$ & $\begin{array}{c}\text { Consultant } \\
\text { Suggestions }\end{array}$ & Stock Return & - \\
\hline 5 & Oil Price & $\begin{array}{c}\text { Presidential } \\
\text { Election }\end{array}$ & $\begin{array}{c}\text { Social } \\
\text { Networks } \\
\text { News }\end{array}$ & - & - \\
\hline 6 & - & - & Informal News & - & - \\
\hline
\end{tabular}

According to collected data, regarding economic factors, respondents consider foreign investments $(35 \%)$, exchange rate $(26 \%)$, interest rate $(21 \%)$, inflation rate $(10 \%)$ and oil price (8\%) factors respectively as the most influential variables on their financial decision behavior. Considering political factors, respondents consider U.S news (45\%), E.U news (32\%), presidential election (12\%), internal news (6\%) and Asia news (5\%) factors respectively as the most influential variables on their financial decision behavior. Regarding psychological factors, respondents consider informal news (27\%), Social network news (23\%), firms' announcements $(16 \%)$, broker's suggestions (13\%), consultant suggestions (11\%) and stock market news (10\%) factors respectively as the most influential variables on their financial decision behavior. According to internal financial reports, respondents consider stock return (42\%), income statement (28\%), balance sheet (18\%) and financial ratio (12\%) factors respectively as the most influential variables on their financial decision behavior. Finally, in market return features respondents consider stock price trend (62\%), risk and return (22\%) and earning yield (16\%) factors respectively as the most influential variables on their financial decision behavior. Table 2 shows correlation between research variables. According to respondents opinions, political factors $(\mathrm{r}=0.816)$ are the most important parameters which have meaningful effects on investor's financial behavior, and the lowest relationship belongs to internal financial reports $(\mathrm{r}=$ 0.412).

Table 2: Variables and financial decision behavior correlation.

\begin{tabular}{|c|c|c|c|c|}
\hline Variables & $\begin{array}{c}\text { Correlation } \\
\text { Coefficient }\end{array}$ & Purchase & Sell & $\begin{array}{c}\text { Transaction variable } \\
\text { (Buying and selling) }\end{array}$ \\
\hline \multirow{3}{*}{ Political } & Pearson & 0.752 & 0.763 & 0.816 \\
\cline { 2 - 5 } & Sig (two-tailed) & 0.000 & 0.000 & 0.000 \\
\cline { 2 - 5 } & $\mathrm{N}$ & 258 & 258 & 258 \\
\hline \multirow{3}{*}{ Economic } & Pearson & 0.689 & 0.597 & 0.713 \\
\cline { 2 - 5 } & Sig (two-tailed) & 0.000 & 0.000 & 0.000 \\
\cline { 2 - 5 } & $\mathrm{N}$ & 258 & 258 & 258 \\
\hline \multirow{3}{*}{$\begin{array}{c}\text { Psychological } \\
\text { Internal financial } \\
\text { reports }\end{array}$} & Pearson & 0.673 & 0.644 & 0.648 \\
\cline { 2 - 5 } & Sig (two-tailed) & 0.000 & 0.000 & 0.000 \\
\cline { 2 - 5 } & Sig (two-tailed) & 0.000 & 0.000 & 258 \\
\cline { 2 - 5 } & Pearson & 258 & 258 & 0.459 \\
\hline \multirow{3}{*}{\begin{tabular}{c} 
Market return \\
\cline { 2 - 5 }
\end{tabular}} & Sig (two-tailed) & 0.000 & 0.000 & 0.000 \\
\cline { 2 - 5 } & Pearson & 258 & 258 & 0.458 \\
\hline
\end{tabular}


The path analysis must be statistically reliable, thus, RMSEA should be calculate. RMSEA measure the error of the statistical sample, degree of freedom and model's estimation. RMSEA is 0.0119 that is less than 0.5 which is prove the model accuracy. According to path analysis and intermediary variable, Table 3 shows variable interactions and their final effects on financial behavior decisions of investors.

Table 3: Variables effectiveness on financial behavior.

\begin{tabular}{|c|c|c|c|}
\hline Research Variables & Direct effect & Indirect effect & Overall effect \\
\hline Political factors & $78 \%$ & $16 \%$ & $84 \%$ \\
\hline Economic factors & $63 \%$ & $12 \%$ & $73 \%$ \\
\hline Psychological factors & $56 \%$ & - & $56 \%$ \\
\hline Internal financial reports factors & $37 \%$ & - & $37 \%$ \\
\hline Market return factors & $43 \%$ & - & $43 \%$ \\
\hline
\end{tabular}

\section{Conclusion}

Behavioural finance can be a beginning of a major transformation in financial theories. The combination of financial theory with other social sciences resulted in the appearance of behavioural finance. Behavioural finance concentrates on investment decision making process. Behavioural finance emphasized that it is not possible to separate an investor's personality and the investment decisions that they may make. Thus, individual financial behaviour of capital market investors is turn into crucial issue. Investor behaviour is no only based on financial theory, but also is highly affected by his psychological features. Finally, we have to confess that behavioural finance is not a perfect alternative for classical finance assumptions, but it can have a better explanation for certain financial phenomena.

In present study we examine psychological factors besides four other factors in order to their effects on financial behaviour of investor in Tehran Stock Exchange (TSE) as the most important capital market in Iran. The results shows that the investor political factors as the most important effective variables on their financial behaviours. The second factor in their opinion is economic factors and the third one is psychological variables. Internal financial reports and market features are not have important effectiveness as three pervious factors.

\section{References}

[1] Barberis, N., Thaler, R. A survey of behavioural finance, Handbook of the Economics of Finance.1nd edition. Elsevier Science B.V. publishing; 2003, 1053-1128.

[2] Birau, F. R. Behavioral Finance Paradigm And Its Implications On Investment Decisions, International Scientific Conference, ECO-TREND 2011 - Exit From The Crisis And Revival Of Sustainable Growth. 8th edition, November 25-26, Romania, 2011.

[3] Birau, F. R. The meanings of efficient market paradigm in the context of emerging capital markets. An analysis of weak-form efficiency on the Bucharest Stock Exchange, The International Conference, Competitiveness And Stability In The Knowledge Based Economy, The Faculty of Economics and Business Administration, University of Craiova, 4-5 November, Romania, 2011.

[4] Fama, E. Efficient Capital Markets: a review of theory and empirical work, The Journal of Finance. Vol. 25, No. 2, 1970, 383-417. 
[5] Fama, E. Market effciency, long-term returns, and behavioural finance, Journal of Financial Economics. 49, 1998, 283-306.

[6] Fama, E. Random Walks in Stock Market Prices, Financial Analysts Journal. 1965, 55-59.

[7] Fromlet, H. Behavioral Finance Theory and Practical Application, Business Economics. (36) No 3, 2001, 63-69.

[8] Gromb, D., Vayanos, D. Limits of Arbitrage: The State of the Theory, the Paul Woolley Centre Working Paper Series. No 9, Discussion Paper, 2010, No 650.

[9] Gregor, A., and Mitchell, Mark L. and Stafford, E. New Evidence and Perspectives on Mergers. Harvard Business School Working Paper. 2001, 01-070.

[10] Hill, C.A. The political determinants of investor's behaviour, Uniwin University, 1997.

[11] Houthakker, H., Williamson, P. The Economics of Financial Markets, Oxford University Press, Inc., New-York, 1996.

[12] Luce, D. Utility of Gains and Losses: Measurement theoretical and Experimental Approaches, Mahwah, New Jersey: Lawrence Erlbaum Publishers, 2000, ISBN 0805834605.

[13] Malkiel, B. The Efficient Market Hypothesis and Its Critics, Princeton University, CEPS Working Paper. 2003, No. 91, 59-82.

[14] Mathews, J. A Situation-Based Decision-Making Process, Journal of Organisation Behaviour, IV (3), 2005, 19-25.

[15] Ritter, J. Behavioral Finance, Published, with minor modifications, in the Pacific-Basin Finance Journal. Vol. 11, No. 4, 2003, 429-437.

[16] Ross, S. The Interrelations of Finance and Economics: Theoretical Perspectives, American Economic Review. May, 77:2, 1987, 29 -34.

[17] Samuelson, P. Proof That Properly Anticipated Prices Fluctuate Randomly, Industrial Management Review, 1965, 41-49.

[18] Sewell, M. Behavioural Finance, University of Cambridge, April 2010, 1-13.

[19] Sharpe, W., Alexander, G. Investments, 4th Edition. Englewood Cliffs, NJ: Prentice Hall, 1990, 194.

[20] Thaler, R. Advances in Behavioral finance, Journal of political economy. 1990, vol. 98, 703-73.

*Corresponding author.

E-mail address: mojtaba.mortezaee1984@gmail.com 